\title{
Japanese Encephalitis vector abundance and infection frequency in Cuddalore District, Tamil Nadu, India: a five-year longitudinal study
}

\author{
P. Philip Samuel, D. Ramesh, V. Thenmozhi, J. Nagaraj, M. Muniaraj, N. Arunachalam \\ Centre for Research in Medical Entomology, Indian Council of medical Research, Department of \\ Health Research, Madurai, India
}

\begin{abstract}
An entomological monitoring of Japanese encephalitis vectors from the Cuddalore district, Tamil Nadu was undertaken at biweekly intervals for $1 \mathrm{hr}$ after dusk for five years to find out the abundance and JE virus activity longitudinally in three villages. A total of 95,644 vectors belonging to 31 species constituted predominantly by Culex vishnui subgroup and Culex gelidus $98.5 \%$. JE virus was identified from $C x$. tritaeniorhynchus (18), Cx. vishnui (1) and Cx. gelidus (6) giving infection rate of $0.482,0.608$ and 0.221 respectively. Abundance of $C x$. tritaeniorhynchus and $C x$. gelidus differed significantly by area, season and year $(\mathrm{P}<0.05)$ whereas $C x$. vishuni differed significantly by season and year $(\mathrm{P}<0.05)$. Transmission was not observed throughout all the seasons and the infection rate was recorded maximum during HotWet season 0.46 (confidence interval: 0.17-1.02). Culex tritaeniorhynchus dominated the catch and the Culex gelidus steadily increased in its abundance during this period compared to the earlier studies conducted from these areas which acts as a secondary vector along with the major vector, $C x$. tritaeniorhynchus.
\end{abstract}

Correspondence: Paulraj Philip Samuel, Centre for Research in Medical Entomology, Indian Council of medical Research, Department of Health Research, 4, Sarojini Street, Chinnachokkikulam, Madurai-625002, India. Tel.: +91.452.2525131; +91.9443168056 - Fax: 0452.2530660.

E-mail: philipsamuelpaulraj@gmail.com

Key words: Culex tritaeniorhynchus; Cx. gelidus and Cx. vishnui; infection rate; Japanese encephalitis; Cuddalore.

Acknowledgments: we are grateful to the Secretary, DHR \& Director General, ICMR and Dr. B. K. Tyagi for providing the facilities, encouragement, guidance and suggestions for the study. We are greatly indebted to the field staff of DPH \&PM, Tamil Nadu for their assistance during the field visits. Sincere thanks are due to all the supporting staff of CRME, both Field Station and Hq. Madurai.

Received for publication: 12 November 2015.

Revision received: 29 July 2016.

Accepted for publication: 29 July 2016.

(C) Copyright P. Philip Samuel et al., 2016

Licensee PAGEPress, Italy

Journal of Entomological and Acarological Research 2016; $48: 5630$

doi:10.4081/jear.2016.5630

This article is distributed under the terms of the Creative Commons Attribution Noncommercial License (by-nc 4.0) which permits any noncommercial use, distribution, and reproduction in any medium, provided the original author(s) and source are credited.

\section{Introduction}

Japanese encephalitis is a serious public health problem in Asia with $30,000-50,000$ clinical cases reported annually. Over the past 60 years, it has been estimated that JE has infected $\sim 10$ million children globally, killing 3 million and causing long-term disability in 4 million ${ }^{1}$. In India cases of JE have been reported from 26 out of 29 states and 7 union territories occasionally since 1978 and repeated outbreaks were reported from 12 states. JE is now reported under the umbrella of acute encephalitis syndrome. Annual reported cases due to JE range between 1714 and 6727 while recorded deaths due to JE range between 367-1684 (Ministry of Health and Family Welfare Government of India, 2010).

JE remained endemic in some districts of Tamil Nadu, where it mainly affects children. A prospective serological study of rural children and sentinel pigs in Cuddalore district revealed high rates of seroconversion to flaviviruses, the majority of which were caused by JE virus infection (Gajanana et al., 1995). It was suggested that maintenance and handling of goats and cattle is easier than pigs and screening goats and cattle can be used as a tool to predict the risk of JE infection to humans (Rajendran et al., 2003). The most important vectors are Culex tritaeniorhynchus Giles and Culex vishnui Theobald, from which the largest number of isolations were made (Reuben et al., 1988; Philip Samuel et al., 2000). However, JE virus was isolated from 16 species of mosquitoes (Philip Samuel et al., 2000). In addition, recently the role of An. subpictus as a secondary vector and also to maintain the JE virus by transovarial transmission in Cuddalore was reported (Thenmozhi et al., 2006). An entomological sampling was undertaken to review the vector abundance and JE virus activity longitudinally in the three villages, viz., Kodikkalam situated in Sirumangalam Primary Health Centre-PHC, Eraiyur situated in Sirumangalam PHC and Soundarasolapuram SS Puram) situated in Pennadam PHC in the Cuddalore district Tamil Nadu from April 2006 to March 2011.

\section{Materials and methods}

A longitudinal study of vector abundance and infection frequency was conducted from April 2006 to March 2011 in three villages viz., Kodikkalam, SS Puram and Eraiyur of Cuddalore district (Figure 1) which are located about 5-10 kms distance away from each other. The villages receive irrigation water for cultivation of paddy by double crop pattern through a canal from the Wellington Reservoir. Tamil Nadu receives rain showers from July to August under the influence of the Southwest monsoon, and heavier rainfall from September to December from the Northeast monsoon. There are no extremes of temperature and during the study period, maximum and minimum 
temperatures ranged from 30 to $41^{\circ} \mathrm{C}$ with relative humidity ranged from 70 to $89 \%$ over the whole time period.

Each village was sampled at biweekly intervals from April 2006 to March 2011. There were no fixed sites for mosquito collections. Two collectors moved freely throughout the village and caught both bloodengorged and unfed adult female culicines resting on bushes and thatched roofs of cattle sheds and human dwellings. Mosquitoes were collected for $1 \mathrm{~h}$ after dusk by aspiration and flashlight, transported to the field laboratory, lightly anesthetized with ether, identified to species and sorted on ice into pools of maximum 50 specimens each and screened. Unfed mosquitoes were pooled, whereas engorged females were held for $48 \mathrm{~h}$ for digestion of blood meals before pooling. A key prepared by Reuben et al., (1994) was used for identification of members of the $C x$. vishnui subgroup. Voucher specimens were deposited in the Centre for Research in Medical Entomology (CRME) Museum and the mosquito pools were screened for virus infection (Kimura-Kuroda et al., 1983; Reuben et al., 1994; Gajanana et al., 1997; Philip Samuel et al., 1998).

A significant difference between the area (3 villages), seasons and years was done by using analysis of variance (ANOVA) in SPSS version 16.0. The number of JE positive mosquitoes per 1000 individuals was estimated from ELISA and IFA results by maximum likelihood estimation (MLE) using CDC software programme pooled infection rate version 3.0 (Biggerstaff, 2006). The Chi-square test was used to find out the variation in infection rate between the study villages and different seasons by using Epi Info version 3.5.3.

\section{Results}

We collected 95,644 female mosquitoes belonging to 31 species. Among the total catch, $C x$. tritaeniorhynchus was the most dominant species (55.8\%) followed by $C x$. gelidus (40.29\%) and Cx. vishnui (2.43\%) and these three species comprised of $98.5 \%$ of the total. The overall abundance of $C x$. vishnui was very less compared to the other

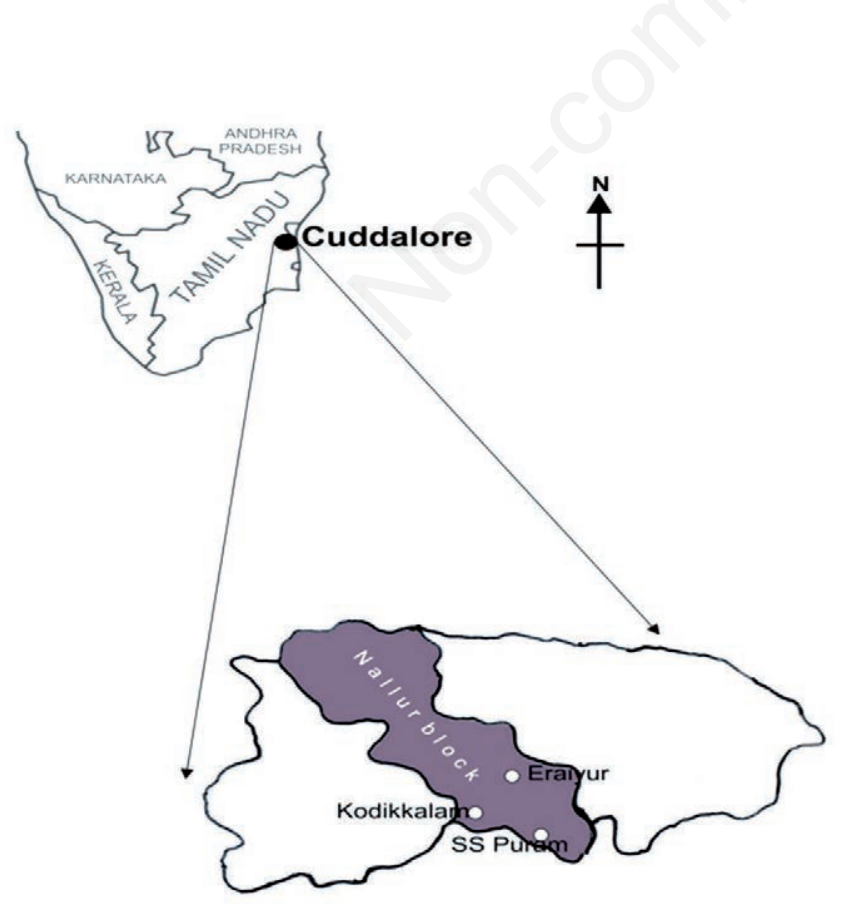

Figure 1. Study areas in Cuddalore district, Tamil Nadu, South India. two vector species ( $C x$. tritaeniorhynchus and $C x$. gelidus) and thus not included for the comparative analysis. The analysis between the three areas which followed the same two cropping pattern was carried out to know whether there exist any variation in the vector abundance.

In all these 3 villages, $C x$. tritaeniorhynchus abundance increased from July-August, coinciding with the beginning of the monsoon rains and rice cultivation and remained elevated from October to February coinciding with the JE transmission season and started decreasing from March and remained low until June the JE non-transmission season. Since all these areas fall under the double crop areas, there were two peaks between July to January coinciding with the $1^{\text {st }}$ (July to September) and $2^{\text {nd }}$ crop (October to January) (Figures 2-4).

Culex gelidus was collected aplenty during the year 2006 and 2007 and the higher peak of PMHD was observed in SS Puram village during the month of September 2006 (466.25) and 2007 (664.5), in Kodikkalam village during the months of March 2007 (181) and another peak abundance was found during July 2007 (192) and in Eraiyur during the months of September 2006 (233) and February 2007(299). Thus the abundance of $C x$. gelidus was usually observed in 3 seasons only Cool-Dry (in all the villages SS Puram 2008-11, Kodikkalam and Eraiyur 2007), Cool-Wet (Eraiyur 2007-9) and Hot-Wet seasons (Eraiyur 2006; SS Puram \& Kodikkalam 2007) (Figure 3-5).The peak $C x$. vishnui abundance was recorded in SS Puram village during the months of October 2006 (66) and April 2009 (36), in Kodikkalam village during July 2006 (52), June 2008(42.5) and June 2009 (41) and in Eraiyur during September 2006(72), October 2006 (56.5) and 2007 October (48) (Figures 2-4).

Culex tritaeniorhynchus abundance was more during the Cool-Wet season in all the three villages (SS Puram-157.64 \pm 1.18 , Kodikkalam$185.5 \pm 1.18$ and Eraiyur-187.55 \pm 1.13 ). But during the Hot-Dry and HotWet seasons significant difference was observed $(\mathrm{P}<0.05)$. In all these 3 villages abundance of this species during different seasons varied significantly $(\mathrm{P}<0.001)$ (Table 1$)$. SS Puram showed high abundance of Culex gelidus in all the seasons compared to all the other villages especially maximum collection was recorded during the Cool-Dry season (144.36 \pm 1.26$)$. In all these villages the abundance during a particular season varied significantly $(\mathrm{P}<0.001)$. Except Kodikalam all the other villages showed significant difference in all the 4 seasons $(\mathrm{P} \leq 0.005)$ (Table 2). The abundance of $C x$. tritaeniorhynchus and $C x$. gelidus differed significantly by area, season and year $(\mathrm{P}<0.05)$ whereas that of $C x$. vishnui differed significantly by season and year $(\mathrm{P}<0.05)$. Significant interaction between area \& season and season \& year was observed only for $C x$. gelidus $(\mathrm{P}<0.05)$ (Table 3$)$.

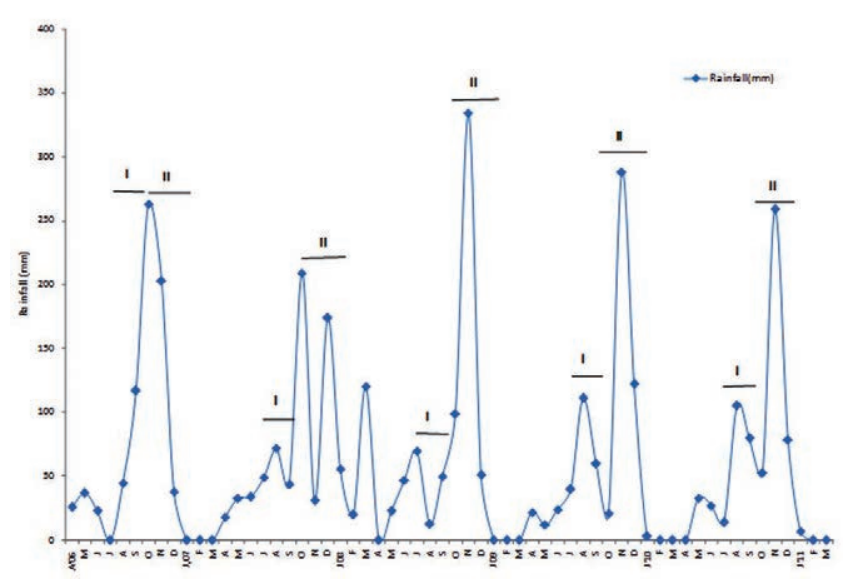

Figure 2. Rainfall in Cuddalore district (2006-2011). 
In total, $25 \mathrm{JE}$ virus isolations were obtained of which 18 isolations were from $C x$. tritaeniorhynchus, 1 from $C x$. vishnui and 6 from $C x$. gelidus, giving infection rate (MLE) of $0.482,0.608$ and 0.221 respectively along with overall infection rate of 0.378 ) was observed. Infection rate of individual species indicate that $C x$. vishnui has higher value of 0.608 when compared to other species. Infection rate of these three species $C x$. tritaeniorhynchus, $C x$. vishnui and $C x$. gelidus were not statistically significant (Tables 4 and 5). From April 2006 to March 2011, 66,654 adult female mosquitoes (1403 pools) comprising of the 37,750 $C x$. tritaeniorhynchus in 755 pools, 1,644 Cx. vishnui in 55 pools and 27,260 Cx. gelidus in 1403 pools were tested for virus infection.

The virus infection was noticed for the months of July 2007, December 2007 \& January 2008 in $C x$. tritaeniorhynchus mosquito species. The overall infection rate of $C x$. tritaeniorhynchus was observed as 0.58 during this year and it was $3.64,1.29,1.03$ during the months of July 2007, Dec. 2007 and Jan 2008. During 2009-10, JE virus infection was observed in $C x$. tritaeniorhynchus (13 pools) in the months October \& November and the virus infection rate was observed to be 1.29 and 1.82 respectively. The overall virus infection rate of $C x$. tritaeniorhynchus was observed as 0.62 during the month of April 2009 to March 2010. Culex tritaeniorhynchus collected in SS Puram area got high infection rate of 0.85 (CI: 0.46-1.44) but showed no significant difference in seasons (Table 5).

Culex gelidus mosquito species was found positive during the months of July 2007 \& January 2008. Virus infection was noticed higher in $C x$. gelidus than $C x$. tritaeniorhynchus in the month of January

Table 1. Seasonal geometric mean abundance by area and season for Cx. tritaeniorhynchus and Cx. gelidus in Cuddalore district.

\begin{tabular}{|c|c|c|c|c|c|c|c|c|}
\hline \multirow[t]{2}{*}{ Season } & \multicolumn{4}{|c|}{ Cx. tritaeniorhynchus } & \multicolumn{4}{|c|}{ Cx. gelidus } \\
\hline & SS Puram & Kodikkalam & Eraiyur & $\begin{array}{c}\text { F-test } \\
\text { (P value) }\end{array}$ & SS Puram & Kodikkalam & Eraiyur & $\begin{array}{l}\text { F-test } \\
\text { (P value) }\end{array}$ \\
\hline April-June (H-D) & $36.34 \pm 1.33$ & $43.98 \pm 1.30$ & $14.41 \pm 1.38$ & $0.021^{*}$ & $62.63 \pm 1.26$ & $5.79 \pm 1.53$ & $8.34 \pm 1.42$ & $<0.001^{* *}$ \\
\hline July-Sep (H-W) & $38.75 \pm 1.36$ & $82.51 \pm 1.21$ & $33.19 \pm 1.33$ & $0.043^{*}$ & $45.05 \pm 1.44$ & $10.29 \pm 1.50$ & $6.10 \pm 1.63$ & $0.005^{*}$ \\
\hline Oct-Dec (C-W) & $157.64 \pm 1.18$ & $185.50 \pm 1.18$ & $187.55 \pm 1.13$ & 0.67 & $67.91 \pm 1.23$ & $12.30 \pm 1.26$ & $50.43 \pm 1.35$ & $<0.001^{* *}$ \\
\hline Jan-Mar (C-D) & $59.44 \pm 1.31$ & $132.14 \pm 1.25$ & $85.29 \pm 1.41$ & 0.15 & $144.36 \pm 1.26$ & $10.93 \pm 1.40$ & $33.33 \pm 1.39$ & $<0.001^{* *}$ \\
\hline F- test (Pvalue) & $0.001^{*}$ & $<0.001^{* *}$ & $<0.001^{* *}$ & & $0.022 *$ & 0.458 & $<0.001^{* *}$ & \\
\hline
\end{tabular}

C-D, cool-dry; H-W, hot-dry; H-W, hot-wet; C-W, cool-wet. *Significant $(\mathrm{P}<0.05)$; **highly significant $(\mathrm{P}<0.001)$.

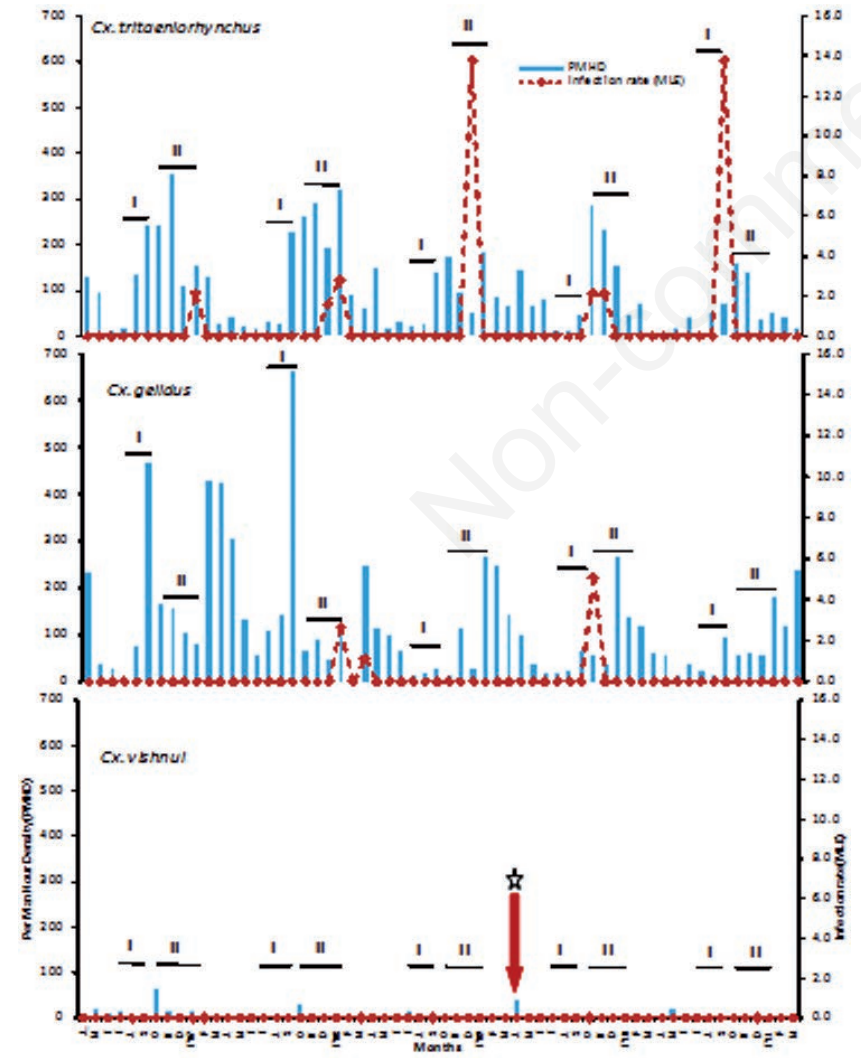

Figure 3. Per Man hour density and infection rate of JE vectors in SS Puram, Cuddalore district (2006-2011). Cx. vishnui only one pool tested found positive. I-First Crop (July-September), IISecond Crop (October-January).

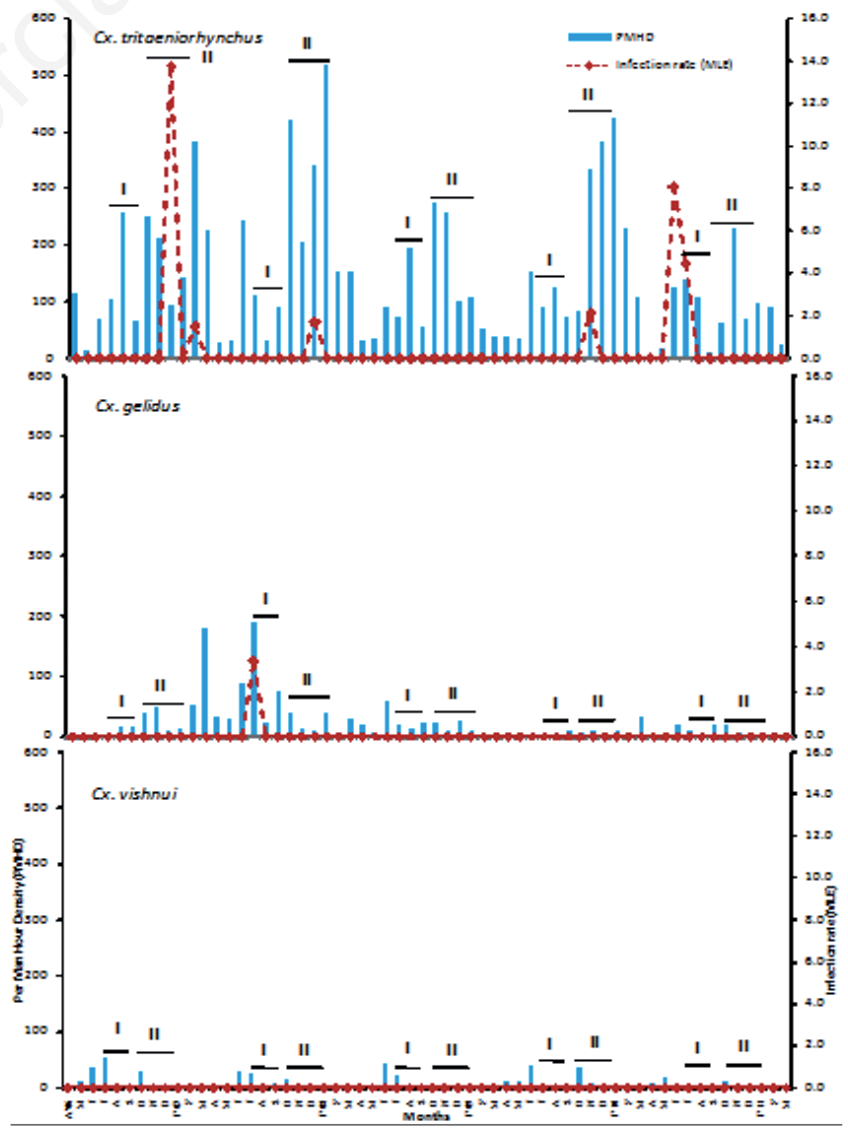

Figure 4. Per Man hour density and infection rate of JE vectors in Kodikkalam, Cuddalore district (2006-2011). I-First Crop (JulySeptember), II-Second Crop (October-January). 


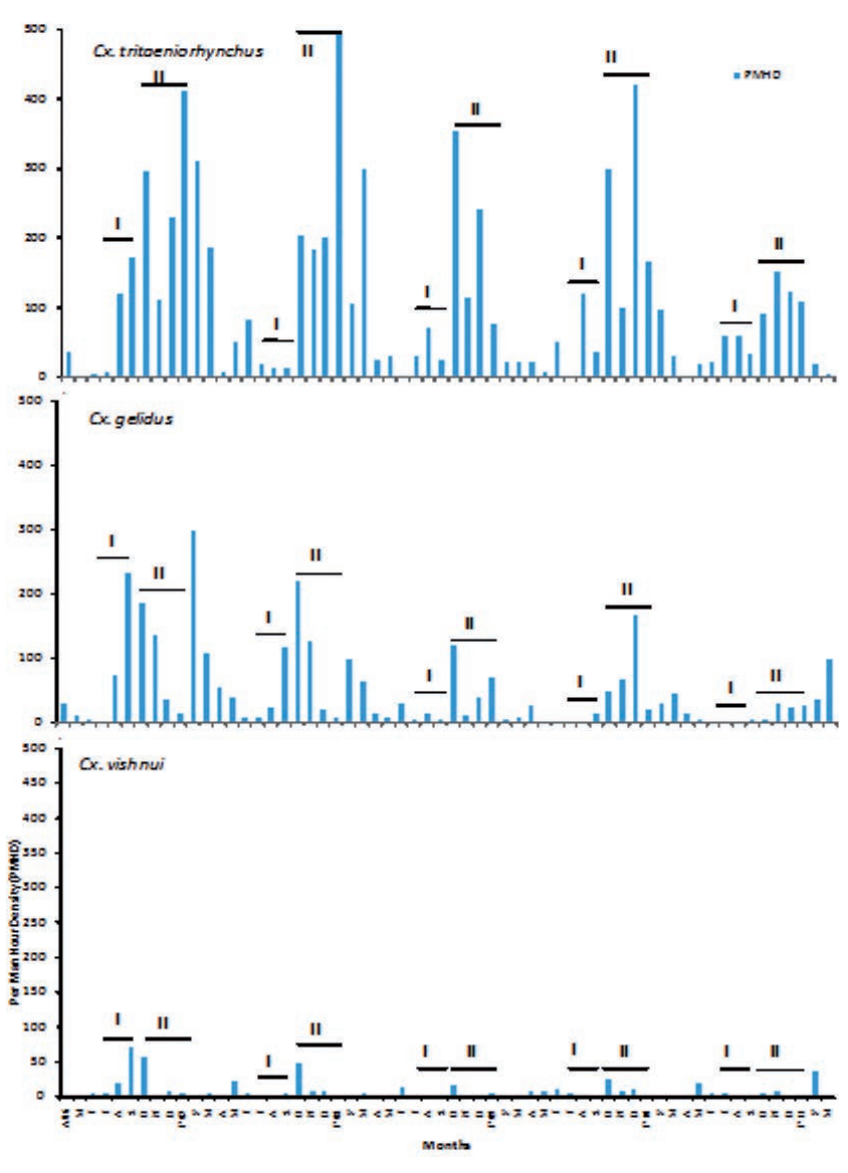

Figure 5. Per Man hour density and infection rate of JE vectors in Eraiyur, Cuddalore district (2006-2011). I-First Crop (JulySeptember), II-Second Crop (October-January).
2008. During the year 2008-2009, the virus infection in vector mosquitoes was found very low level. But the virus infection during 2009-10, in Culex gelidus was observed during the month of October-09 (1 pool) and in $C x$. vishnui during the month of April-09 (1 pool). In addition to that one pool of each $C x$. vishnui and $C x$. gelidus were also found positive. The average infection in vector mosquitoes was $5.68 \%$.

\section{Discussion}

The JE virus is maintained mainly through the biological transmission between vertebrate hosts by the vector mosquitoes. In India JE virus has so far been isolated from 16 species of mosquitoes (Philip Samuel et al., 2000). The Culex vishnui subgroup of mosquitoes has been implicated as the proven vectors of JE in southern India (Reuben et al., 1988; Philip Samuel et al., 2000). In this study conducted from April 2006 to March 2011, Culex tritaeniorhynchus 55.8\% and CX. gelidus $40.29 \%$ were the most abundant species, accounting for $96.09 \%$ of the total catch. But the overall abundance of $C x$. vishnui was very less $(2.43 \%)$ compared to the other two previously mentioned $C x$. tritaeniorhynchus and $C x$. gelidus mosquitoes. A similar 3 year study undertaken from August 1991-July 1994 in the same Cuddalore district showed Culex tritaeniorhynchus $62.6 \%$ and Cx. vishnui $20.1 \%$ (Gajanana et al., 1997). Similarly from here during July 1998-May 2000 the abundance of Culex tritaeniorhynchus $80.46 \%$ and $C x$. vishnui $2.39 \%$ was observed (Rajendran et al., 2003). The present study was similar to a 2-y longitudinal entomological survey conducted in the adjoining North Arcot District (Reuben, 1971). Longitudinal entomological studies conducted in the JE cases reported villages from Cuddapah district showed Culex vishnui subgroup dominated (42.6\%) (Murty et al., 2002). Culex tritaeniorhynchus was recorded as a predominant vector (55.8\%) from the 1990s itself $62.6 \%$ (Gajanana et al., 1997 ) and $80.46 \%$ (Rajendran et al., 2003). In all these studies conduct-

Table 2. Analysis of variance of abundance for Cx. tritaeniorhynchus, Cx. vishuni and Cx. gelidus in three villages of Cuddalore district.

\begin{tabular}{|c|c|c|c|c|}
\hline Variable & df & Cx. tritaeniorhynchus & $\begin{array}{c}\text { F-test } \\
C x . \text { vishnui }\end{array}$ & Cx. gelidus \\
\hline Area & 2 & $6.99 *$ & 0.45 & $54.64^{*}$ \\
\hline Season & 3 & $31.25^{*}$ & $12.13^{*}$ & $10.69 *$ \\
\hline Year & 4 & $4.84^{*}$ & $4.88^{*}$ & $11.05^{*}$ \\
\hline Area $\times$ Season & 6 & 1.94 & 1.79 & $3.48^{*}$ \\
\hline Area $\times$ Year & 8 & 0.31 & 1.13 & 1.44 \\
\hline Season $\times$ Year & 12 & 1.49 & 1.33 & $2.98 *$ \\
\hline Area $\times$ Season $\times$ Year & 24 & 0.94 & 0.74 & 0.98 \\
\hline
\end{tabular}

df, degree of freedom. * Significant $(\mathrm{P}<0.05)$.

Table 3. JE virus isolations from mosquitoes in the villages of Cuddalore district, April 2006 - March 2011.

\begin{tabular}{lccccc} 
Species & No. Pools tested & No. positive & Infection rate & \multicolumn{2}{c}{$\begin{array}{c}\text { Confidence intervals } \\
\text { Upper limit }\end{array}$} \\
Cx. tritaeniorhynchus & $755(37,750)$ & 18 & 0.482 & 0.295 & 0.747 \\
Cx. vishnui & $55(1644)$ & 1 & 0.608 & 0.035 & 2.951 \\
\hline Cx. gelidus & $593(27,260)$ & 6 & 0.221 & 0.090 & 0.458 \\
Total & $1403(66,654)$ & 25 & 0.378 & 0.250 & 0.550 \\
\hline
\end{tabular}


Table 4. JE virus infection rate of Culex mosquitoes related to area and season in villages of Cuddalore district.

\begin{tabular}{|c|c|c|c|c|c|c|c|c|}
\hline \multirow[t]{2}{*}{ Villages } & \multicolumn{2}{|c|}{ Cx. tritaeniorhynchus } & \multicolumn{2}{|c|}{ Cx. vishnui } & \multicolumn{2}{|c|}{ Cx. gelidus } & \multicolumn{2}{|c|}{ Total } \\
\hline & $\begin{array}{c}\text { Pools } \\
\text { (+ve.)/tested }\end{array}$ & Infection rate & $\begin{array}{c}\text { Pools } \\
(+ \text { ve. }) / \text { tested }\end{array}$ & Infection rate & $\begin{array}{c}\text { Pools } \\
\text { (+ve.)/tested }\end{array}$ & $\begin{array}{l}\text { Infection rate } \\
\text { (CI) }\end{array}$ & $\begin{array}{c}\text { Pools } \\
(+ \text { ve. }) / \text { tested }\end{array}$ & Infection rate \\
\hline S.S.Puram & $12 / 288$ & $0.85(0.46-1.44)$ & $1 / 14$ & $2.22(0.13-10.88)$ & $3 / 421$ & $0.15(0.04-0.40)$ & $16 / 723$ & $0.46(0.27-0.73)$ \\
\hline Kodikkalam & $6 / 264$ & $0.46(0.19-0.95)$ & $0 / 21$ & 0.00 & $3 / 60$ & $1.40(0.37-3.80)$ & $9 / 345$ & $0.57(0.28-1.04)$ \\
\hline Eraiyur & $0 / 203$ & 0.00 & $0 / 20$ & 0.00 & $0 / 112$ & 0.00 & $0 / 335$ & 0.00 \\
\hline $\begin{array}{l}\text { Significance } \\
\left(\chi^{2}-\text { Test }\right)\end{array}$ & \multicolumn{2}{|c|}{$8.90(\mathrm{P}<0.05)$} & \multicolumn{2}{|r|}{$2.98(P>0.05)$} & \multicolumn{2}{|c|}{$11.00(\mathrm{P}<0.05)$} & \multicolumn{2}{|c|}{$8.19(\mathrm{P}<0.05)$} \\
\hline \multicolumn{9}{|l|}{ Season } \\
\hline $\begin{array}{l}\text { Jan. - Mar. } \\
\text { (C - D) }\end{array}$ & 6/236 & $0.51(0.21-1.07)$ & $0 / 5$ & 0.00 & $3 / 242$ & $0.26(0.07-0.70)$ & $9 / 483$ & $0.39(0.19-0.71)$ \\
\hline $\begin{array}{l}\text { Apr. - Jun. } \\
\text { (H - D) }\end{array}$ & $1 / 75$ & $0.27(0.02-1.29)$ & $1 / 15$ & $2.45(0.14-12.00)$ & $0 / 89$ & 0.00 & $2 / 179$ & $0.25(0.04-0.81)$ \\
\hline $\begin{array}{l}\text { July. - Sep. } \\
(\mathrm{H}-\mathrm{W})\end{array}$ & $3 / 98$ & $0.62(0.16-1.67)$ & $0 / 13$ & 0.00 & $2 / 122$ & $0.36(0.06-1.18)$ & $5 / 233$ & $0.46(0.17-1.02)$ \\
\hline $\begin{array}{l}\text { Oct. - Dec. } \\
(\mathrm{C}-\mathrm{W})\end{array}$ & $8 / 346$ & $0.47(0.22-0.89)$ & $0 / 22$ & 0.00 & $1 / 140$ & $0.16(0.01-0.79)$ & $9 / 508$ & $0.38(0.18-0.69)$ \\
\hline $\begin{array}{l}\text { Significance } \\
\left(\chi^{2}-\text { Test }\right)\end{array}$ & 0.58 & $(\mathrm{P}>0.05)$ & & $2.72(\mathrm{P}>0.05)$ & 1.64 & $(\mathrm{P}>0.05)$ & & $(P>0.05)$ \\
\hline
\end{tabular}

C-D, cool-dry; H-W, hot-dry; H-W, hot-wet; C-W, cool-wet.

ed in the Cuddalore district the abundance of $C x$. gelidus steadily increased from 4.2\% (Gajanana et al., 1997) and 12.38\% (Rajendran et al., 2003) to the present level of $40.29 \%$. But the abundance of $C x$. fuscocephala (0.84\%) was gradually decreasing compared to the earlier studies from the same areas $6.7 \%$ and $1.23 \%$ (Gajanana et al., 1997; Rajendran et al., 2003). In the same way the abundance of $C x$. pseudovishnui (0.0031\%) also gradually decreased from $0.6 \%$. Culex tritaeniorhynchus abundance was more during the Cool-Wet season (SS Puram- 157.64 \pm 1.18 , Kodikkalam-185.5 \pm 1.18 and Eraiyur$187.55 \pm 1.13$ ) in all the study villages which showed no significant difference $(\mathrm{P}>0.05)$ and coincided with the extensive paddy cultivation and heavy rain fall from the post monsoon season. Culex tritaeniorhynchus has been recognized for many years as the major vectors and play an important role in the epidemiology of JE in India.

All these villages practice double-cropping pattern of rice cultivation which is also related to the rain fall pattern observed from August to December. The presence of $C x$. tritaeniorhynchus was observed throughout the year but the high abundance of this species was mainly restricted to the months of rice cultivation. Thus the abundance was recorded mainly from August to February in this study (Figures 2-4). Similar observations were also reported from these areas (Gajanana et al., 1997; Rajendran et al., 2003) and also in Andhra Pradesh (Murty et al., 2002). The close proximity of houses of villagers to animal sheds also added as an additional factor that increased exposure of the human population to vector mosquitoes (Murty et al., 2002). A similar behaviour was observed in Vellore district, where members of the $C x$. vishnui subgroup predominated during the Northeast monsoon (Reuben, 1971).

Culex tritaeniorhynchus yielded the greatest number of isolates (18) with an overall infection rate of 0.482 , followed by $C x$. gelidus (6) and $C x$. vishnui (1), giving an infection rate of 0.221 and 0.608 . Infection rate obtained for $C x$. tritaeniorhynchus in other studies were as follows: in India 0.28 (Gajanana et al., 1997) and 1.4 (Rajendran et al., 2003). Culex gelidus has been found in breeding habitats with abundant aquatic vegetation and organic content (Mogi et al., 1999) recorded the breeding of $C x$. gelidus in turbid pools. The overall infection rate of $C x$. tritaeniorhynchus was observed as 0.58 during this year and it was
3.64, 1.29, 1.03 during the months of July 2007, Dec. 2007 and Jan 2008 coinciding with the extensive paddy cultivation and heavy rain fall during the monsoon season.

It is clear from the present study and earlier studies that the $C x$. gelidus can act as a vector along with the primary vector $C x$. tritaeniorhynchus. Thus, $C x$. gelidus might play an important role in the enzootic cycle that usually precedes the epidemic. It was concluded that Cx. gelidus might play an important role in the enzootic cycle (Geevarghese et al., 1994).

In the previous Cuddalore Tamil Nadu study, number of JE virus isolates was higher in $C x$. tritaeniorhynchus than $C x$. gelidus but infection rate of $C x$. gelidus (0.52) was higher than $C x$. tritaeniorhynchus $(0.28)$ (Gajanana et al., 1997). But in the present study, JE virus isolates was higher in $C x$. tritaeniorhynchus (18) than $C x$. gelidus (6) and the infection rate of $C x$. tritaeniorhynchus (0.48) was higher than $C x$. gelidus (0.22). Culex gelidus is highly zoophagic and poorly anthrophagic and therefore may have an important role in amplifying JE virus transmission (Reuben et al., 1992). There is a possibility of maintenance of JE virus in nature by $C x$. gelidus.

$\mathrm{JE}$ is basically a rural disease because of the major JE vectors breed in rice fields. Majority of the JE cases in Tamil Nadu were reported soon after monsoon and peak during late August to early September and start to decline from October (Gunasekaran et al., 2012). In these villages, animals live very close proximity to human dwellings. There are only makeshift animal sheds where cattle, buffaloes and goats are housed, but no separate pig sties or separate pig rearing farms. During the night, pigs take shelter next to human dwellings and often share human dwellings and cattle sheds. Unorganized pig rearing is an important for the weaker sections of the communities who mainly live in rural areas. The people who rear them for their livelihood are virtually living along with the animals under the same roof. The infected vector abundance of JE will increase as well as its potential to infect human because of the high pig population in Asia (Endy \& Nisalak, 2002). The method to detect the viral antigens using the desiccated mosquito surveillance system could be effectively used for surveillance of JE virus activity in endemic areas (Tewari et al., 2008) in collaboration with the health department, which will be effective in identifying 
high-risk areas and to initiate appropriate control measures to avoid future outbreaks.

\section{Conclusions}

An entomological monitoring of Japanese encephalitis vectors from the Cuddalore district, Tamil Nadu was undertaken for five years to find out the abundance and JE virus activity longitudinally in three villages. Mosquitoes belonging to 31 species of which Culex tritaeniorhynchuss, Culex vishnui and Culex gelidus constituted $98.5 \%$ of adult females. More isolations of JE virus were identified from $C x$. tritaeniorhynchus, $C x$. vishnui and $C x$. gelidus. Abundance of $C x$. tritaeniorhynchus and $C x$. gelidus differed significantly by area, season and year whereas $C x$. vishuni differed significantly by season and year. Transmission was not observed throughout all the seasons and the infection rate was recorded maximum during Hot-Wet season. Culex tritaeniorhynchus dominated the catch during this period. Culex gelidus showed steady increase in its abundance contrary to the earlier studies conducted in these areas. Culex gelidus acts as a secondary vector along with the major vector, $C x$. tritaeniorhynchus.

\section{References}

BIGGERSTAFF B.J., 2006 - PooledInfRate, version 3.0: A Microsoft Excel add-in to compute prevalence estimates from pooled samples. Centers for Dis. Cont. Prevention Fort Collins, CO.

ENDY T.P., NISALAK A., 2002 - Japanese encephalitis virus: ecology and epidemiology. -Curr. Topics in Microbiol. Immunol. 267: 11-48.

GAJANANA A., RAJENDRAN R., PHILIP SAMUEL P., 1997 - Japanese encephalitis in South Arcot District, Tamil Nadu, and India: a three-year longitudinal study of vector-abundance and infection frequency. - J. Med. Entomol. 34: 651-659.

GAJANANA A., RAJENDRAN R., THENMOZHI V., 1995 - Comparative evaluation of bioassay and ELISA for detection of Japanese encephalitis virus in field collected mosquitoes. - SE Asian J. Trop. Med.Pub.Hlth.

GEEVARGHESE G., MISHRA A.C., GEORGE JACOB P., 1994 - Studies on the mosquito vectors of Japanese encephalitis virus in Mandya district, Karnataka, India. - Southeast Asian J. Trop. Med. Pub. Hlth. 25: $378-82$.

GUNASEKARAN P., KAVERI K., KAVITHA ARUNAGIRI., 2012 - Japanese encephalitis in Tamil Nadu (2007-2009). - Indian J. Med. Res. 2012; 135: 680-682.

KIMURA-KURODA J., YASURI K., 1983 - Topographical analysis of antigenic determinants on envelope glycoprotein V3 (E) of Japanese encephalitis virus, using monoclonal antibodies. - J. Virol. 45:124-132.

MINISTRY OF HEALTH AND FAMILY WELFARE GOVERNMENT OF INDIA., 2010 -Operational guide for Japanese encephalitis vaccination in India September. - Available from: http//health.bih.nic.in /Docs/Guidelines-Japanese-Encephalitis.pdf

MOGI M., SUNAHARA T., SELOMO M., 1999 - Mosquito and aquatic predator communities in ground pools on lands deforested for rice field development in central Sulawesi, Indonesia. - J. Am. Mosq. Cont. Associ. 15: 92-97.

MURTY US., SATYAKUMAR D.V., SRIRAM K., 2002 - Seasonal prevalence of Culex vishnui subgroup, the major vectors of Japanese encephalitis virus in an endemic district of Andhra Pradesh, India. - J. Am. Mosq. Cont. Assoc. 18: 290-293.

PHILIP SAMUEL P., HIRIYAN J., GAJANANA A., 2000 - Japanese encephalitis virus infection in mosquitoes and its epidemiological implications. - ICMR Bull. 30: 37-43.

PHILIP SAMUEL P., HIRIYAN J., THENMOZHI V., BALASUBRAMANIAN A., 1998 - A system for studying vector competence of mosquitoes for Japanese encephalitis virus. - Indian J. Malariol. 35: 146-150.

RAJENDRAN R., THENMOZHI V., TEWARI S.C., 2003 - Longitudinal studies in South Indian villages on Japanese encephalitis virus infection in mosquitoes and seroconversion in goats. -Trop. Med. Inter. Hlth. 8: 174 -181.

REUBEN R.,1971 - Studies on the mosquitoes of North Arcot District, Madras state, India. Part 6. Seasonal prevalence of the Culex vishnui group of species. - J. Med. Entomol. 8: 367-371.

REUBEN R., KAUL H.N., SOMAN R.S., 1988 - Mosquitoes of arboviral importance in India. - Mosq. Borne Dis. Bull. 5: 48 -54.

REUBEN R., TEWARI S.C., HIRIYAN J., 1994 - Illustrated keys to species of Culex (Culex) associated with Japanese encephalitis in Southeast Asia (Diptera: Culicidae). -Mosq. System. 26: 75-96.

REUBEN R., THENMOZHI V., SAMUEL P.P., 1992 - Mosquito blood feeding patterns as a factor in the epidemiology of Japanese encephalitis in Southern India. - Am. J. Trop Med. Hyg. 46: 654-663.

TEWARI S.C., THENMOZHI V., ARUNACHALAM N., PHILIP SAMUEL P., TYAGI B.K., 2008 - Desiccated vector mosquitoes used for the surveillance of Japanese encephalitis virus activity in endemic southern India. - Trop. Med. Intl. Hlth. 13: 286- 290.

THENMOZHI V., RAJENDRAN R., AYANAR K., 2006 - A long-term study on Japanese encephalitis virus infection in An.subpictus in Cuddalore district, Tamil Nadu, south India. - Trop. Med. Inter. Hlth. 11: 288-293. 